\title{
REVIEW | Vinyl: The Analogue Record in the Digital Age
}

Dominick Bartmanski and lan Woodward

London and New York: Bloomsbury, 2015

ISBN: $9780857856180(\mathrm{HB}) ; 9780857856616(\mathrm{~PB}) ;$

9780857857316 (ePDF); 9780857856586 (ePub)

\section{Nabeel Zuberi \\ University of Auckland \\ n.zuberi@auckland.ac.nz}

Only a few years ago Will Straw (2012: 235) remarked that, "If there has been a material turn in music studies, it has, for the most part, gone unnamed". The positive aspect of this failure to name any major shift is that popular music scholars have long acknowledged the materialization of music in recording and playback technologies, and in music's commodification in media industries. On the flip side, the materiality of music may have been taken for granted and therefore insufficiently theorized; sociological and musicological approaches have skated over the substances in which musical sounds are embedded and used. In recent years, studies of mobile music (Gopinath and Stanyek 2014) and formats (Sterne 2012) have redressed this problem and offered avenues for more materialist music studies that engage historically with musical objects, and question the apparent "immateriality" of contemporary digital media (Morris 2015).

The significant revival of vinyl in recent years may have contributed to the growth in scholarship on the medium across several disciplines. To Richard Osborne's (2014) history, we can add Bartmanski and Woodward's combination of cultural sociology and material culture studies, which situates itself in the "sensory turn", promises to focus on the "thingness" of the analogue record as an object, and moves beyond the concern with collecting that dominates academic writing on the wax platter. The authors interviewed record label owners, musicians, technicians, retailers and consumers, primarily in Berlin, Brisbane and 
Tokyo, and visited an enviable number of record stores in other locations too. Though the rock canon and the classic album are given their dues, refreshingly the book places greater emphasis on the vinyl worlds of DJ culture, dance clubs and electronic music.

Chapter 1 lays out a general history of the "lives of the king format" from its rise in the 1950s to its high point in the 1960s and 1970s, its relative decline with the ascendancy of the CD in the 1980s and 1990s, and modest resurgence in the twenty-first century of downloading and streaming music. During its fallow periods, small-scale independent record companies releasing dance music genres and hip-hop have sustained vinyl, primarily as 12 -inch singles and albums. Arguably vinyl remains a marker of underground authenticity in these scenes, despite software such as Traktor and Serato making digital DJ-ing more common.

Chapter 2, "Medium: Handling and Hearing", more concertedly applies phenomenological perspectives to the diverse functions and practices associated with records. The authors supplement discursive approaches by attending to the affordances and agency of these objects as they interact with human beings. The planning and serendipity of "crate digging" involve the challenges and pleasures of social engagement and navigating the archives and spaces in music stores. The chapter then turns to how listeners describe their listening pleasures, from the "warm" and "organic" imperfections of analogue sound to the procedural elements of playing records in homes and public venues - from the demands a long-playing record (LP) places on the listener's time, to DJ manipulations such as mixing and scratching, and the centrality of the record to dancing in clubs.

Chapter 3, "Thing", hones in on the sensory, physical object as an icon and tool, rather than as a figure of representation. Bartmanski and Woodward consider vinyl's "sticky entrapment or entanglement" (65) in technological assemblages with other equipment such as turntables and sound systems. They explore the material and creative parameters of mastering, cutting and pressing records with the technicians responsible for these processes. Their respondents discuss the sonic, visual and haptic pleasures of these packaged objects as DJs and consumers, returning repeatedly to the limitations and imperfections of the medium as central to vinyl's attraction. The authors argue that record collections offer insights into a "sensory formation and its histories", and that records are "genuine phenomenological anchors for our ritual memories" (98).

Chapter 4, "Commodity", focuses on the different kinds of economic, cultural and social value that vinyl accrues through distinctive pathways in music economies dominated by digital media. The examples show how differentiated and mutable the value of records can be. Rarity in secondhand markets inflates the price of singles and albums at record fairs and through influential online marketplaces such as Discogs. Ownership of records often articulates a sense of self and helps to construct identities. Consumers are willing to pay more for the vinyl format, even if the music is available in cheaper commodity form. The value of particular issues or pressings of the same recording can rise or fall depending on its reissue on vinyl. Record companies may adopt strategies of batch production or limited editions that often inflate the price and demand for releases. A vinyl record can also have the effect of legitimating the seriousness of an artist, as more tangible evidence of their work than digital formats. As mixed media with its cover or sleeve, the record is valued as an art object. Vinyl constitutes a 
heritage and canon of recorded music. The chapter gives a strong sense of multiple markets, institutional locations, and volatile forms of value that may operate for any particular record

Chapter 5, "Totems", considers how vinyl occupies urban spaces, particularly the "vinylscapes" of music stores and clubs. Large archival stores that feature canonical recordings and secondhand stock are distinct from DJ-centered stores, which are usually smaller and more specialist in terms of genre. In lifestyle and boutique stores, vinyl browsers might be "gliders" rather than "diggers," as they buy coffee, electronics or home furnishings. Vinyl materializes a cosmopolitan ethos, can sustain marginal music scenes, be integral to tourism, or add visual flavour and cultural specificity to bars and restaurants.

In the book's epilogue, Bartmanski and Woodward return to their phenomenological argument for the agency of the vinyl record. Vinyl is an essential study of a residual technology's new lives and meanings in the digital age. It reminds us of the high regard and continuing desire for haptic and visual experiences with aesthetic objects steeped in idiosyncratic rituals with their own sense of time. Screens are not enough. The book is written with love for vinyl records, their aesthetics and the forms of social life they foster. The interviews reveal the tropes of today's wax poetics and discophilia. In trying to avoid the pathological discourse of 'vinyl junkies,' the authors may have retreated too much from a critique of vinyl's role in social and cultural differentiation. The economic critique of music companies currently overpricing new and reissued vinyl might also have been more pointed. Also almost all the book's interviewees are white European men.

With an emphasis on the object itself, vinyl's relationships to gender, race and the politics of representation are sidelined. However, Vinyl is a vital work to spin, mix and play off more textualist feminist scholarship and critical race studies on phonographic culture (Robertson-Wojcik 2001; Stilwell 2006; Gilroy 1993; Weheliye 2005).

\section{References}

Gilroy, P. 1993. "Wearing Your Art on Your Sleeve: Notes Toward a Diaspora History of Black Ephemera". In Small Acts: Thoughts on the Politics of Black Cultures. London: Serpents Tail: 237-257.

Gopinath, S. and Stanyek, J. Eds. 2014. The Oxford Handbook of Mobile Music Studies, Vol. 1. Oxford: Oxford University Press.

Morris, J.W. 2015. Selling Digital Music, Formatting Culture. Oakland, CA: University of California Press.

Osborne, R., 2014. Vinyl: A History of the Analogue Record. Aldershot: Ashgate.

Robertson-Wojcik, P., 2001. "The Girl and the Phonograph; or the Vamp and the Machine Revisited". In P. Robertson-Wojcik and A. Knight Eds., Soundtrack Available: Essays on Film and Popular Music. Durham: Duke University Press: 433-454.

Stilwell, R. 2006. "Vinyl Communion: The Record as Ritual Object in Girls' Ritesof-passage Films". In P. Powrie and R. Stilwell Eds. Changing Tunes: The Use of Pre-existing Music in Film. Aldershot: Ashgate: 152-166. 
Sterne, J. 2012. MP3: The Meaning of a Format. Durham: Duke University Press. Straw, W. 2012. "Music and material culture". In M. Clayton, T. Herbert and R. Middleton Eds. The Cultural Study of Music: A Critical Introduction. $2^{\text {nd }}$ Edition. London and New York: Routledge: 227-236.

Weheliye, A. G. 2005. Phonographies: Grooves in Sonic Afro-modernity. Durham: Duke University Press. 